\title{
The Incidence of Alpha-Thalassemia in Iraqi Turks
}

\author{
Irak'lı Türklerde Alfa-Talassemi Sıklığı
}

\author{
Duran Canatan \\ Hemoglobinopathy Diagnosis Center of Mediterrenaean Blood Diseases Foundation, Antalya, Turkey
}

\section{To the Editor,}

I read the article on the "The incidence of alpha-thalassemia in Iraqi Turks". Esmale et al showed that 8 of the 83 participants were diagnosed with alpha-thalassemia an incidence rate of $9.6 \%$ and particularly $3.7 \mathrm{~kb}$ deletion in Iraqi Turkmens [1].

Although the incidence studies of alpha thalassemia in Turkey are rare, more frequently hemoglobin $\mathrm{H}$ disease has been observed in south of Turkey, The molecular basis of $\mathrm{Hb} \mathrm{H}$ disease was studied and mutations - $\alpha 3.7,-\alpha 4.2$, -MED-I and - $\alpha 20.5$ were found to be responsible for the disease $[2,3]$.

The frequency of alpha-thalassemia was 3.6\% among Turkish newborns in a study that employed globin gene mapping analysis of DNA [4]. In our study, in 13 out of 205 cord blood samples alpha-thalassemia was found $6.3 \%$. There was mistake at incidence so hat we improved with erratum [5]. The incidence of $\beta$-thalassemia trait was very high level, the incidence of $\alpha$-thalassemia trait was also found high level (6.3\%) in Antalya district.

We are observing a lot of uncertain couples with alpha thalassemia in premarital screening tests in hemoglobinopathy diagnosis center of in Antalya, it needs molecular diagnostic test to all of them.

As conclusion, the incidence of alpha-thalassemia was much higher in the Iraqi Turks in the present study than that reported in studies from Turkey. It needs more molecular diagnostic studies in especially adults in Turkey.

\section{Conflict of Interest Statement}

The authors of this paper have no conflicts of interest, including specific financial interests, relationships, and/ or affiliations relevant to the subject matter or materials included.

\section{References}

1. Esmael A, Öztürk A, Akar N: The incidence of alphathalassemia in Iraqi Turks.Turk J Haematol 2011; 28: 235-236

2. Oner C, Gürgey A, Oner R, Balkan H, Gümrük F, Baysal E, Altay C: The molecular basis of $\mathrm{Hb} \mathrm{H}$ disease in Turkey. Hemoglobin 1997; 21: 41-51

3. Taştan AÖ, Canatan D, Başak AN: A search for the $\alpha$-thal-2 determinants - $\alpha 3.7$ and - $\alpha 4.2$ in the newborns from Antalya district of Turkey: Cord blood study using the PCR method. Balkan Journal of Medical Genetics 1999; 2: 23-25

4. Fei YJ, Kutlar F, Harris HF 2nd, Wilson MM, Milana A, Sciacca P, Schiliro G, Masala B, Manca L, Altay C: A search for anomalies in the zeta, alpha, beta and gamma globin gene arrangements in normal black, Italian, Turkish, and Spanish newborns. Hemoglobin 1989; 13: 45-65

5. Canatan D, Oğuz N, Güvendik İ, Yıldırım S: The Incidence of Alpha-Thalassemia in Antalya-Turkey. Turk J Haematol 2002; 19: 433-434

Address for Correspondence: Duran CANATAN, M.D.,

Güllük Cd. Antelsan İş Merkezi 8/3 07050 Antalya, Turkey

Phone: +90 24224320 20/21 E-mail: dcanatan@superonline.com

Received/Geliş tarihi : August 25, 2011

Accepted/Kabul tarihi : August 26, 2011 